anales de psicología / annals of psychology

2020, vol. 36, $\mathrm{n}^{\circ} 3$ (october), 533-542

https://doi.org/10.6018/analesps.405391
(C) Copyright 2020: Editum. Servicio de Publicaciones de la Universidad de Murcia. Murcia (Spain) ISSN print edition: 0212-9728. ISSN online edition (http://revistas.um.es/analesps): 1695-2294. Online edition License Creative Commons 4.0: BY-SA

\title{
Personality and job creativity in relation to engagement in nursing
}

\author{
María del Mar Molero-Jurado ${ }^{1}$, María del Carmen Pérez-Fuentes ${ }^{1,2^{*}}$, José Gabriel Soriano ${ }^{1}$, Begoña María Tortosa ${ }^{1}$, \\ Nieves Fátima Oropesa ${ }^{1}$, María del Mar Simón-Márquez ${ }^{1}$, and José Jesús Gázquez-Linares ${ }^{1,3}$ \\ 1 University of Almeria (Spain) \\ 2 Universidad Politécnica y Artística del Paraguay (Paraguay) \\ 3 Universidad Autónoma de Chile (Chile)
}

\begin{abstract}
Título: Personalidad y percepción de la creatividad en el tranajo sobre el engagement en enfermería.

Resumen: La personalidad está integrada por un conjunto de atributos individuales que, en interacción con factores tanto endógenos como exógenos, van a caracterizar la forma de pensar, sentir y actuar. Desde esta perspectiva, la personalidad puede relacionarse en el contexto laboral con la percepción de la creatividad y con el compromiso que se adquiere en el trabajo. Este trabajo tiene como objetivo analizar la implicación de la personalidad y la percepción de la creatividad en el trabajo sobre el engagement en los profesionales de enfermería. Se evaluó una muestra de 1268 profesionales de enfermería, entre los 22 y 63 años, de los cuales un $85.3 \%$ fueron mujeres y un $14.7 \%$ hombres, con una media de edad de 32.24 años $(D T=6.68)$ y 32.79 años $(D T=6.27)$ respectivamente. Para la recogida de datos se aplicaron diferentes instrumentos, como el Big Five Inventory (BFI-10), la escala Creative Environment Perceptions (CEP) y_el instrumento Utrecht Work Engagement Scale (UWES). El modelo de mediación confirmó que la percepción de la creatividad en el contexto laboral ejerció un papel mediador en la relación entre personalidad y engagement. En particular, los datos confirman que presentar un perfil de personalidad con puntuaciones elevadas en todas las dimensiones de la personalidad, a excepción del neuroticismo, además de permitir contar con unas características adecuadas en el trabajo, favorece el apoyo a la creatividad lo que, a su vez, repercute positivamente en el engagement. Este trabajo presenta importantes implicaciones para la práctica profesional, destacando la fuerte relación entre compromiso y percepción de la creatividad, relación que apunta hacia la mejora de la percepción de la creatividad y el compromiso del personal de enfermería con su trabajo, mejorando la estabilidad emocional y reforzando el entusiasmo y la inspiración para ser más creativos y competentes con la organización institucional de la que se forma parte.

Palabras clave: Personalidad; Creatividad; Engagement; Enfermería: Salud laboral.
\end{abstract}

\section{Introduction}

Personality is made up of a set of individual attributes and qualities which characterize the way in which a person thinks, feels or acts (Freiberg et al., 2014). One of the most important models in the study of personality in different contexts is the Big Five Factors Model (e.g., John, Donahue, \& Kentle, 1991; John, Naumann \& Soto, 2008; Chang et al., 2016; Deniz \& Satici, 2017; Amorós et al., 2019). John, Naumann and Soto (2008) summarized the five personality factors as (1) Neuroticism, from emotional stability to negative affect (anxiety, nervousness, sadness, tension) (2) Extraversion, facing the social and material world full of energy, sociably, actively, assertively and with positive affect; (3) Agreeableness, prosocial attitudes toward others, that is, al-

* Correspondence address [Dirección para correspondencia]: Dra. $M^{a}$ del Carmen Pérez-Fuentes. University of Almería. Ctra. Sacramento s/n. 04120 Almería (Spain). E-mail: mpf421@ual.es

(Article received: 02-12-2019; revised: 02-04-2020; accepted: 04-05-2020)

\begin{abstract}
Personality is made up of a set of individual attributes, which in interaction with both endogenous and exogenous factors, characterize how one thinks, feels and acts. From this perspective, in the work context, personality can be related with the perception of creativity and with engagement acquired on the job. The purpose of this study was to analyze the involvement of personality and perception of creativity on the job in engagement of nursing professionals. The sample evaluated was made up of 1268 nurses aged 22 to 63 , of whom $85.3 \%$ were women and $14.7 \%$ men, with a mean age of 32.24 years $(S D=6.68)$ and 32.79 years $(S D=6.27)$, respectively. The instruments used to collect the data were the Big Five Inventory (BFI-10), the Creative Environment Perceptions Scale (CEP) and the Utrecht Work Engagement Scale (UWES). The mediation model confirmed that perception of creativity in the work context exerted a mediating role in the relationship between personality and engagement. In particular, the data confirmed that having a personality profile with high scores in all the personality dimensions except neuroticism, in addition to providing adequate characteristics for the job, favors creativity, which in turn, has a positive repercussion on engagement. This study presents important implications for professional practice, emphasizing the strong relationship between engagement and perception of creativity, a relationship which points toward improved engagement of nurses with their work, improving emotional stability and reinforcing the enthusiasm and inspiration for being more creative and competent with the institutional organization they are part of.

Keywords: Personality; Creativity; Engagement; Nursing; Occupational
\end{abstract} health. truism, tenderness, trust and modesty; (4) Conscientiousness, the ability to control impulses to direct behavior toward goals or objectives; (5) Openness to experiences, flexibility, depth, originality and both the mental and experiential complexity that can characterize a person's life.

In the work context, personality has been found to be related to factors such as stress, motivational values or access to entrepreneurial activity, which are associated with performance and improvement of professional practice (Cheng et al., 2020; Nurhasanah et al., 2020; Pérez-Fuentes et al., 2019a, Tehrani et al., 2013, Sovia et al., 2018). In recent years, these findings have contributed to its being dealt with, to a certain extent, as a variable subject to research in the healthcare context, where the Extraversion personality factor has been demonstrated to be the most highly correlated with personal competency (Lcho et al., 2019). In another direction, all the personality factors, except Neuroticism, have been found to be related positively to subjective vitality, that is, with an active, enthusiastic and joyful attitude (Bhargavi et al., 2017; Pillai, 2018; Uysal et al., 2014). 
One of the factors in organizational productivity and employee wellbeing, engagement, has become the organizational one-best-way, where passion and effort are considered components of productivity (Liu \& Johnston, 2019). Engagement refers to the responsibility employees feel to the organization they belong to (Molero et al., 2018). This construct is defined by three basic dimensions: Vigor, Dedication and Absorption (Schaufeli \& Bakker, 2003), and refers to their feeling of wellbeing (Othman \& Nasurdin, 2019). For a long time, it was defined as the antithesis of burnout, which reduces the professional's quality of life (Bakioğlu \& Kiraz, 2019; Vizoso-Gómez \& Arias-Gundín, 2018). Vigor is characterized by a high level of energy and mental resilience when faced with difficulties. Dedication is being strongly involved in one's work. Absorption implies being fully concentrated and engrossed in one's work, experiencing a feeling of enjoyment associated with the desire to continue working. Of these three dimensions, Absorption and Vigor best predict engagement and help nurses to attain the desired goals (Abbas et al., 2013; García et al., 2015). Work engagement has been associated with social support (Bakker \& Demorouti, 2013), job satisfaction (Yan et al., 2019) and emotional intelligence (Pérez-Fuentes et al., 2018). Other authors have suggested that personality exerts considerable influence on engagement level (Taris et al., 2017; Tisu et al., 2020). Previous studies have also shown that professional who have a lower level of Neuroticism and high levels of Extraversion, Openness to Experience and Conscientiousness show stronger engagement (Çelik \& Oral, 2016; Langelaan et al., 2006; Njoku et al., 2017; Panacio \& Vandenberghe, 2012; Taherinejad et al., 2017).

Future nursing professionals should acquire those competencies which today's society demands by means of an innovative methodology (Manso et al., 2019). Their learning should therefore be based on development of creative skills (Hsing-Yuan, 2020). This way, they will show more creativity in favor of the scope of the organizational objectives set (Liu et al., 2020; Robins et al., 2018). Moreover, creativity enables one to be attentive to new opportunities (Mussons \& Tarrats, 2018). In the workplace, creativity can be evaluated based on three dimensions: Support for creativity, Job characteristics and Blocks to creativity (Boada-Grau et al., 2014). Support for creativity alludes to the employee superior, working group and organization contributing to their being creative. Job characteristics are those aspects such as available resources, control over work performed and whether the work is challenging. Blocks to creativity show the difficulties placed by the organization to being creative. In this respect, previous studies have shown that personality is related to creativity (Sanz de Acedo et al., 2014) and professional engagement (Mesurado et al., 2018). However, there are few studies explaining the role of creativity in engagement. For example, in the longitudinal study by Xu et al. (2019), proactive team personality was significantly and positively related to team climate for innovation. Furthermore, proactive team personality, Time 1 exerted a cross-level influence on indi- vidual creative performance (as rated by supervisors) and job crafting, and in Time 2, through team climate. In another vein, with respect to the relationship between personality and creativity, Furnham et al. (2013) showed that those who are more creative are more extroverted and open to new experiences (Werner et al., 2014).

These results show that developing an innovative work environment can foster the creative potential of professionals (Mayfield \& Mayfield, 2010), since creative employees who show a positive attitude toward change (Romo et al., 2017) and low levels of neuroticism (Krumm et al., 2018) are needed to favor institutional growth and potentialization. In view of previous studies, this one was intended to progress in the knowledge of engagement, attempting to analyze and confirm the types of relationships between different variables (personality, perception of creativity and work engagement) and, also, further study the mediating effects, in particular, with respect to the role of perception of creative workplaces in the relationship between personality and work engagement. Therefore, the general objective of this study consisted of analyzing the involvement of personality and the perception of work creativity on engagement in nursing professionals. And, as specific objectives to: a) establish the relationships between perception of creativity in the work context, personality and the components of engagement in a sample of nursing professionals; b) analyze personality profiles and determine whether there any any statistically significant differences in the perception of job creativity and engagement; c) identify the mediating role of perception of creativity in the work context on the relationship between personality and engagement.

Based on the evidence above, the following hypotheses were posed: (H1) Personality influences the perception of creativity in the work context and the components of engagement in nursing personnel; (H2) The perception of job creativity and engagement are influenced by the subject's personality profile; (H3) The perception of creativity in the work context exerts a mediating hole on the relationship between personality and engagement.

\section{Method}

\section{Participants}

The original sample was made up of a total of 1383 nursing professionals, residents in the Autonomous Region of Andalusia (Spain). First, as engagement is one of the main variables in the study, all those unemployed during the data collection period were discarded (-68). Then, those with random or incongruent answers to control questions (CQ) were also discarded. There were five errors on $\mathrm{CQ}_{2}, 32$ on $\mathrm{CQ}_{3}$, and 10 on $\mathrm{CQ}_{5}$. After sample filtration, 1268 nurses remained. The mean age of the participants, aged 22 to 63, was 32.02 years $(S D=6.91)$. The sex distribution in the sample was $85.3 \%(n=1081)$ women and $14.7 \%(n=187)$ men, 
with mean ages of $32.24(S D=6.68)$ and $32.79(S D=6.27)$, respectively.

\section{Instruments}

Engagement was evaluated by the Utrecht Work. Engagement Scale (UWES; Schaufeli \& Bakker, 2003). This is a selfreport scale with 17 items rated on a seven-point Likert-type scale. It provides information on three commitment dimensions: Vigor (6 items), Dedication (5 items) and Absorption (6 items). Its psychometric properties show adequate reliability and validity and it has been widely used for nurses (Montgomery et al., 2015; Pérez-Fuentes et al., 2019a).

The 10-item Big Five Inventory (BFI-10; Rammstedt \& John, 2007) was used to evaluate personality dimensions. In this study, the ordinal Alpha calculated for the subscales was .92 for Vigor, .93 for Dedication and .88 for Absorption. This scale is a brief version of the BFI-44 (John et al., 1991). It reports on the Big Five personality factors (Extraversion, Conscientiousness, Agreeableness, Neuroticism and Openness). Previous research has demonstrated that the BFI-10 has psychometric properties comparable in size and structure to the full-scale BFI. Findings back the factor and construct validity and validity of criteria of the BFI-10 (Rammstedt \& John, 2007; Rammstedt et al., 2014).

Finally, perception of the creative work environment was measured using the Creative Environment Perceptions Scale (CEP; Mayfield \& Mayfield, 2010), specifically the Spanish version by Boada-Grau et al. (2014). It consists of nine items with a five-point Likert-type answer format and a three-factor structure: The first, Creativity Support (three items), alludes to the employee's superior, work group and organization encouraging creativity. The second, Work Characteristics (three items) refers to such aspects as available resources, control of work performed and whether the work is challenging. The third, Creativity Blocks (three items), indicates the difficulties placed by the organization on being creative.

\section{Procedure}

The study was approved by the University of Almeria Bioethics Committee (Ref: UALBIO2017/011). Before collecting data, participants were assured that data processing would comply with applicable standards of data security, confidentiality and ethics. The heads of the various healthcare areas were contacted by email, and they distributed the link to workers who agreed to participate in the study. The questionnaire was applied on a Web platform developed by for the purpose the research team, which enabled the questionnaires to be filled out online. The questionnaire contained control questions throughout to avoid random or incongruent answers, and any such cases were discarded from the sample.

\section{Data analysis}

First, a preliminary analysis was done of the variables of creativity in the work context (Creativity Support, Work characteristics, Creativity Blocks), the personality dimensions (Extraversion, Conscientiousness, Agreeableness, Neuroticism, Openness) and the components of engagement (Vigor, Dedication, Absorption), by calculating the Pearson's correlation coefficient in addition to the corresponding descriptive statistics.

Then, taking the personality dimensions as the input variables, a two-stage cluster analysis was performed to identify the different profiles or natural clustering of the dataset. In this case, the objective was classification by mean scores on the personality dimensions, showing the results as a complementary analysis to the rest of the data. In addition, this exploratory technique offers data on cluster quality, a silhouette value measuring cohesion and separation of the clusters, with which the results are analyzed to see whether clusters formed are poor, correct or good. In this case, the mean silhouette found was 0.3 , which is "correct" cluster quality. Once the clusters have been identified a comparison of means is performed to determine whether there are any significant differences between the groups in job crafting and engagement. The Student's $t$ for independent samples was applied for this with the Cohen's $d$ (1988) to evaluate the effect size.

In addition, multiple mediation analyses were computed for each of the components of engagement, taking the personality profile as a predictor variable and the subscales on perception of creativity as potential mediators. The PROCESS macro for SPSS (Hayes, 2013) was used for this. Bootstrapping with coefficients was estimated from 5000 bootstrap samples. Confidence intervals with bootstrapping, as one of the most valid and powerful methods of testing the importance of indirect effects, is frequently used (Hayes, 2009).

To examine the reliability of the instruments used to collect data, the following procedure was used to estimate the internal consistency of the scores: 1) First, an exploratory factor analysis was done on the polychoric correlation matrix using the FACTOR software (Lorenzo-Seva \& Ferrando, 2006). The data were calculated under a criterion of parametric analysis and promin rotation. 2) The Excel spreadsheet developed by Dominguez-Lara (2018) was used to calculate the ordinal alpha coefficient, as it provides that data based the polychoric correlation analysis, and therefore, is better for calculating the reliability of scales with ordinal answers or answers based on a Likert scale (Elosua \& Zumbo, 2008). 


\section{Results}

Perception of job creativity, personality and engagement: correlations and descriptive statistics

As shown in Table 1, the dimensions of the perception of job creativity (creativity support, work characteristics and creativity blocks) were correlated with the personality factors (Extraversion, Agreeableness, Conscientiousness, Openness and Neuroticism) in all cases. Furthermore, the results found revealed correlations of the three components of engagement with the creativity subscales in the job context, and also with all the personality factors.

Table 1. Descriptive statistics and correlations. Job creativity, personality and engagement $(N=1268)$.

\begin{tabular}{|c|c|c|c|c|c|c|c|c|c|c|c|c|}
\hline & $\mathrm{M}$ & SD & 1 & 2 & 3 & 4 & 5 & 6 & 7 & 8 & 9 & 10 \\
\hline 1. APY_C & 3.31 & .85 & - & & & & & & & & & \\
\hline 2. CR_TR & 3.63 & .64 & $.53^{* * *}$ & - & & & & & & & & \\
\hline 3. BLQ_C & 2.86 & .91 & $-.42^{* * *}$ & $-.29^{* * *}$ & - & & & & & & & \\
\hline 4. EXTRA & 3.50 & .80 & $.13^{* * *}$ & $.16^{* * *}$ & $-.13^{* * *}$ & - & & & & & & \\
\hline 5. AMAB & 4.01 & .58 & $.14^{* * *}$ & $.18^{* * *}$ & $-.09^{* *}$ & $.21^{* * *}$ & - & & & & & \\
\hline 6. CONC & 3.87 & .67 & $.17^{* * *}$ & $.19^{* * *}$ & $-.11^{* * *}$ & $.17^{* * *}$ & $.23^{* * *}$ & - & & & & \\
\hline 7. NEURO & 2.67 & .81 & $-.17^{* * *}$ & $-.20^{* * *}$ & $.20^{* * *}$ & $-.19^{* * *}$ & $-.14^{* * *}$ & $-.25^{* * *}$ & - & & & \\
\hline 8. APERT & 3.51 & .74 & $.12^{* * *}$ & $.15^{* * *}$ & $-.11^{* * *}$ & $.13^{* * *}$ & $.13^{* * *}$ & $.29^{* * *}$ & $-.14^{* * *}$ & - & & \\
\hline 9. VI & 4.46 & 1.06 & $.42^{* * *}$ & $.48^{* * *}$ & $-.21^{* * *}$ & $.20^{* * *}$ & $.27^{* * *}$ & $.36^{* * *}$ & $-.18^{* * *}$ & $.23^{* * *}$ & - & \\
\hline 10. DE & 4.45 & 1.17 & $.44^{* * *}$ & $.51^{* * *}$ & $-.25^{* * *}$ & $.19^{* * *}$ & $.24^{* * *}$ & $.32^{* * *}$ & $-.19^{* * *}$ & $.22^{* * *}$ & $.90^{* * *}$ & - \\
\hline 11. $\mathrm{AB}$ & 4.00 & 1.09 & $.38^{* * *}$ & $.43^{* * *}$ & $-.18^{* * *}$ & $.11^{* * *}$ & $.19^{* * *}$ & $.23^{* * *}$ & $-.06^{*}$ & $.16^{* * *}$ & $.83^{* * *}$ & $.82^{* * *}$ \\
\hline
\end{tabular}

Note. APY_C $=$ Creativity support; CR_TR $=$ Work characteristics; BLQ_C $=$ Creativity blocks; EXTRA $=$ Extraversion; AMAB $=$ Agreeableness; CONC $=$ Conscientiousness; NEURO $=$ Neuroticism; APERT $=$ Openness; VI $=$ Vigor; $\mathrm{DE}=$ Dedication; $\mathrm{AB}=$ Absorption. ${ }^{*} p<.05 ; * * p<.01 ; * * * p<.001$.

\section{Personality profiles: Differences in the perception of} creativity and engagement

After verifying the relationships between the study variables, a two-stage cluster analysis was done to classify participants by personality factor scores (Figure 1), producing two groups:

The first cluster (C1), with $37.2 \%$ of cases $(n=472)$, was characterized by scores below the sample mean on the personality factors: Conscientiousness $(M=3.34)$, Agreeableness $(M=3.67)$, Openness $(M=3.07)$, and Extraversion $(M$ $=3.03)$, and above the total mean in Neuroticism $(M=$ 3.07).

The second cluster (C2), which included $62.8 \%$ of the sample $(n=796)$, was characterized by scores above the sample mean in Conscientiousness $(M=4.18)$, Agreeableness $(M=4.22)$, Openness $(M=3.77)$, and Extraversion $(M$ $=3.77)$, and score below the mean in Neuroticism $(M=$ 2.44).

After classification in groups by the two-cluster solution, a Student's $t$-test for independent samples was performed to find out whether there were any differences between clusters in perception of creativity in the work context or the engagement components (Table 2). The mean scores were significantly higher in Creativity support $(t=-6.63, p<.001, d$ $=.39)$ and Work characteristics $(t=-8.29, p<.001, d=.48)$ in Cluster 2 than in Cluster 1, while Creativity blocks $(t=$ $8.78, p<.001, d=.34)$ had the significantly highest mean in Cluster 1.

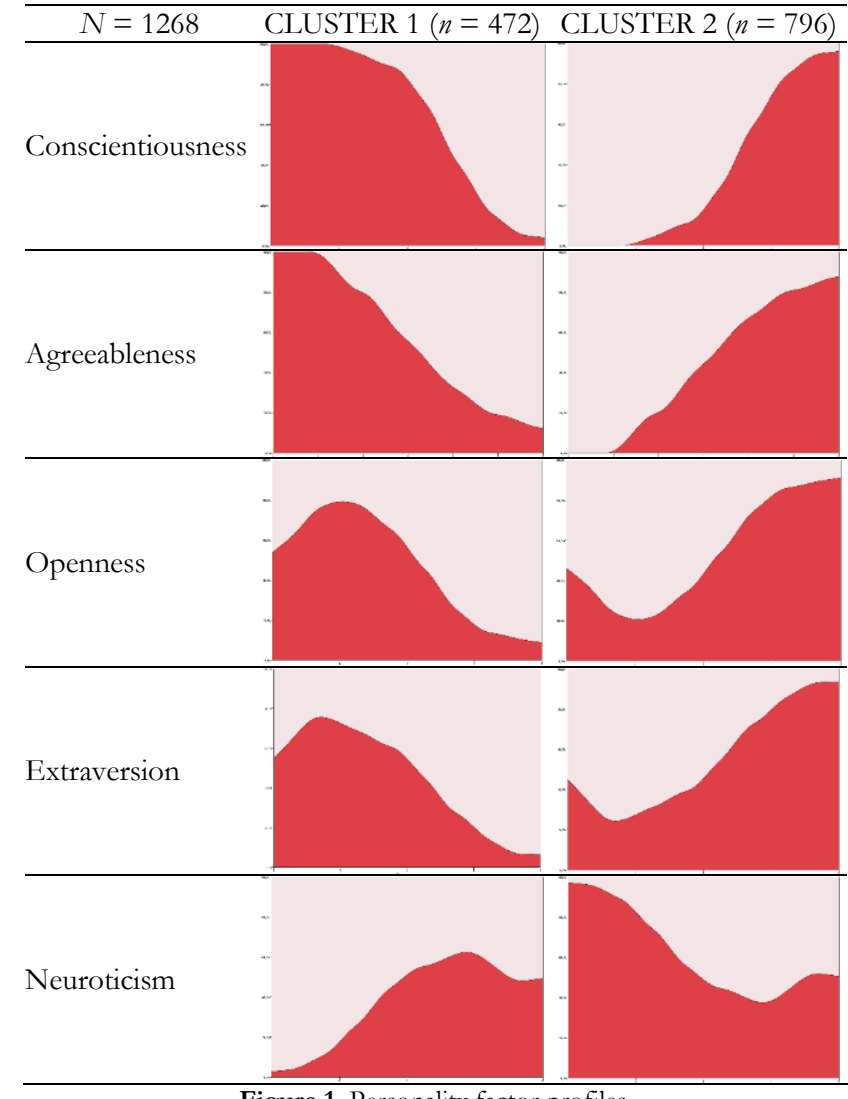

Figure 1. Personality factor profiles.

Note. Factors in order of importance of input. 
Table 2. Creativity in the work context and engagement. Descriptive statistics and $t$-test, by personality profile.

\begin{tabular}{|c|c|c|c|c|c|c|c|c|c|c|}
\hline & & \multicolumn{6}{|c|}{ Cluster } & \multirow{3}{*}{$t$} & \multirow{3}{*}{$p$} & \multirow{3}{*}{ d } \\
\hline & & \multicolumn{3}{|c|}{$\mathrm{c} 1$} & \multicolumn{3}{|c|}{$\mathrm{c} 2$} & & & \\
\hline & & $N$ & $M$ & $S D$ & $N$ & $M$ & $S D$ & & & \\
\hline \multirow[t]{3}{*}{ Creativity } & APY_C & 472 & 3.10 & .79 & 796 & 3.43 & .86 & $-6.63^{* * *}$ & .000 & .39 \\
\hline & CR_TR & 472 & 3.44 & .63 & 796 & 3.75 & .62 & $-8.29^{* * *}$ & .000 & .48 \\
\hline & BLQ_C & 472 & 3.04 & .77 & 796 & 2.75 & .97 & $5.78^{* * *}$ & .000 & .34 \\
\hline \multirow[t]{3}{*}{ Engagement } & VI & 472 & 3.99 & 1.11 & 796 & 4.73 & .92 & $-12.12^{* * *}$ & .000 & .70 \\
\hline & $\mathrm{DE}$ & 472 & 3.98 & 1.20 & 796 & 4.74 & 1.06 & $-11.27^{* * *}$ & .000 & .66 \\
\hline & $\mathrm{AB}$ & 472 & 3.71 & 1.11 & 796 & 4.17 & 1.04 & $-7.29^{* * *}$ & .000 & .42 \\
\hline
\end{tabular}
.001

The comparison of means of engagement components showed that in all cases (VI: $t=-12.12, p<.001, d=.70$; DE: $t=-11.27, p<.001, d=.66$; AB: $t=-7.29, p<.001, d=$ $.42)$, Cluster 2 had significantly higher means than Cluster 1.

\section{Dimensions of creativity in the workplace as predic- tors of engagement in nursing}

According to the data shown in Table 3, the regression analysis offered two models for each of the engagement dimensions, where the second had the most explanatory power, with an explained variance of $27.1 \%$ for Vigor, $30.9 \%$ for
Dedication and $21.8 \%$ for Absorption. In all cases, the factors included in the equation were Work characteristics and Creativity support.

To confirm the validity of the models, residual independence was analyzed. The Durbin-Watson $D$ was 2.01 for Vigor, 1.96 for Dedication and 2.00 for Absorption, which confirms the absence of positive or negative autocorrelation. It may also be observed that the $t$ is associated with a probability of error below .05 in all cases. The standardized coefficients showed that Work characteristics is the factor with the most explanatory weight.

Table 3. Regression analysis for the dimensions of engagement $(N=1268)$.

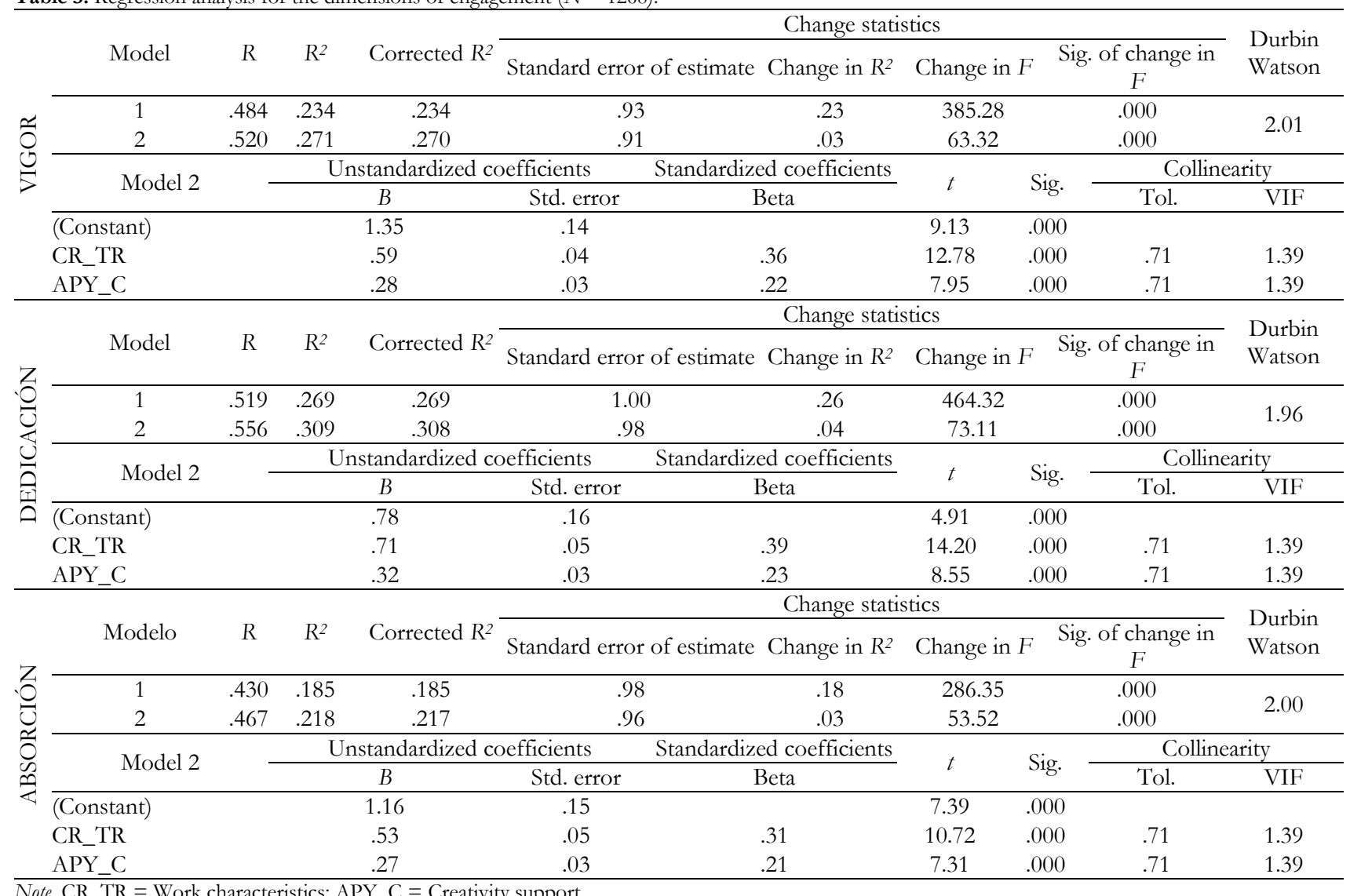

Note. CR_TR $=$ Work characteristics; APY_C $=$ Creativity support 
Finally, to check whether the relationship estimated was affected by multicollinearity, the tolerance statistics and VIF (variance inflation factor) were calculated for each variable. According to the results, absence of collinearity between variables in the model may be assumed. The condition index (14.40), although high, is below the limit of 20 set by Belsley (1991).

\section{Mediation analysis of creativity in the work context on the relationship between personality and en- gagement}

It was found with regard to the third hypothesis, on the mediating effect of creativity on the relationship between personality and engagement, that pertaining to Personality Cluster 2 (high scores in Conscientiousness, Agreeableness, Openness and Extraversion, and a score below the mean in Neuroticism), in addition to having adequate job characteristics, favors creativity support which, in turn, has a positive repercussion on engagement. For this, three multiple mediation models were computed (one for each engagement component) using the work characteristics and creativity support as two mediators operating in series.

In the first place, there was a statistically significant effect $(B=.30, p<.001)$ of personality $(\mathrm{X})$ on work characteristics
$\left(\mathrm{M}_{1}\right)$. The second regression analysis took Creativity support as the result variable $\left(\mathrm{M}_{2}\right)$ and included Personality $(\mathrm{X})$ and Work characteristics $\left(\mathrm{M}_{1}\right)$ in the equation. The latter had a significant effect $(B=.68, p<.001)$ on Creativity support $\left(\mathrm{M}_{2}\right)$, as did Personality $(B=.11, p<.01)$.

Figure 2 shows the mediation model taking Vigor as the dependent variable. Significant effects were found for the independent variable $(B=.49, p<.001)$, and of the two mediators: Work characteristics $(B=.52, p<.001)$ and Creativity support $(B=.25, p<.001)$. The direct effect of personality on Vigor was significant $(B=.49, p<.001)$, with a total effect of the model $B=.74, p<.001$. In the analysis of indirect effects, data were found supporting a significant level for Path 1 [ind $1: \mathrm{X} \rightarrow \mathrm{M}_{1} \rightarrow \mathrm{Y}_{\mathrm{VI}} ; B=.16, S E=.02,95 \% \mathrm{CI}$ $(.114, .217)$ ], Path 2 [ind $2: \mathrm{X} \rightarrow \mathrm{M}_{1} \rightarrow \mathrm{M}_{2} \rightarrow \mathrm{Y}_{\mathrm{VI}} ; B=.05, S E=$ $.01,95 \% \mathrm{CI}(.035, .078)]$ and Path 3 [ind $3: \mathrm{X} \rightarrow \mathrm{M}_{2} \rightarrow \mathrm{Y}_{\mathrm{VI}} ; B=$ $.02, \mathrm{SE}=.01,95 \% \mathrm{CI}(.007, .055)]$. To determine which of the indirect effects or paths was statistically higher than the rest, a mediator comparison (C) test was done: In this case, $\mathrm{C} 1\left[\left(\mathrm{X} \rightarrow \mathrm{M}_{1} \rightarrow \mathrm{Y}_{\mathrm{VI}} * \mathrm{X} \rightarrow \mathrm{M}_{1} \rightarrow \mathrm{M}_{2} \rightarrow \mathrm{Y}_{\mathrm{VI}}\right): .15\right.$, SE $=.02,95 \%$ $\mathrm{CI}(.064, .161)]$ and $\mathrm{C} 2\left[\left(\mathrm{X} \rightarrow \mathrm{M}_{1} \rightarrow \mathrm{Y}_{\mathrm{VI}} * \mathrm{X} \rightarrow \mathrm{M}_{2} \rightarrow \mathrm{Y}_{\mathrm{VI}}\right): .13\right.$, $S E=.02,95 \%$ CI $(.076, .194)]$, showed the existence of statistically significant differences between the indirect effects compared.

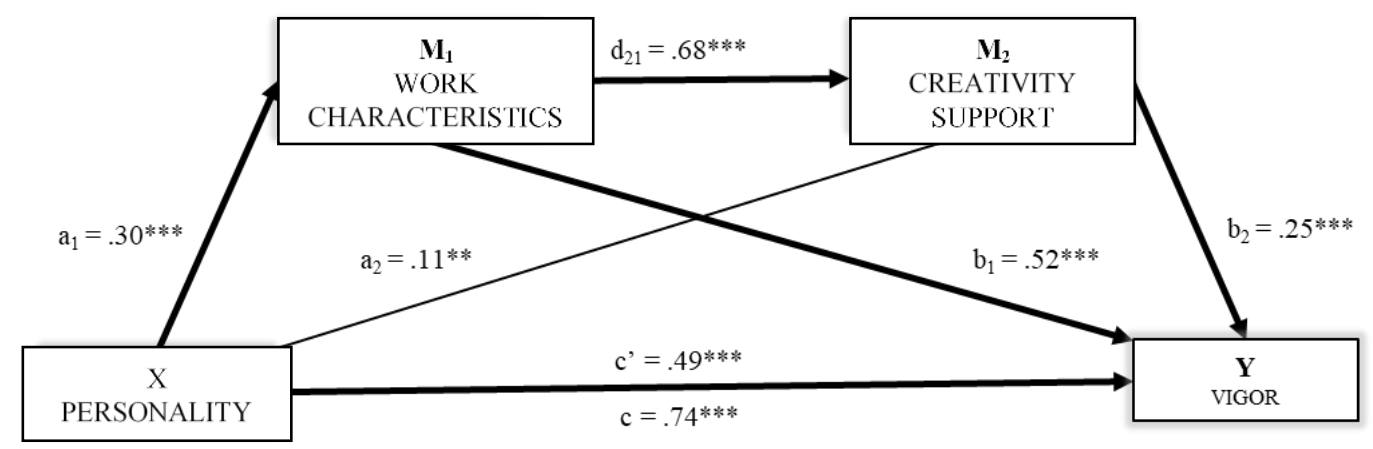

Figure 2. Multiple mediation model for Vigor (Note. $\left.{ }^{* *} p<.01,{ }^{* * *} p<.001\right)$.

In Figure 2, with the Dedication factor as the dependent variable, significant direct effects were observed for Personality $(B=.46, p<.001)$, Work characteristics $(B=.65, p<$ $.001)$, and Creativity support $(B=.30, p<.001)$, with a total model effect of $B=.75, p<.001$. In the analysis of indirect effects, a significant level was found for Path 1 [ind ${ }_{1}$ : $\mathrm{X} \rightarrow \mathrm{M}_{1} \rightarrow \mathrm{Y}_{\mathrm{DE}} ; B=.19, S E=.02,95 \%$ CI $\left.(.146, .264)\right]$, Path
2 [ind $2: \mathrm{X} \rightarrow \mathrm{M}_{1} \rightarrow \mathrm{M}_{2} \rightarrow \mathrm{Y}_{\mathrm{DE}} ; B=.06, S E=.01,95 \% \mathrm{CI}(.043$, $.090)$ ] and Path 3 [ind $3: \mathrm{X} \rightarrow \mathrm{M}_{2} \rightarrow \mathrm{Y}_{\mathrm{DE}} ; B=.03, S E=.01$, $95 \%$ CI $(.009, .064)]$. The comparison analysis found statistically significant differences in comparisons of indirect effects $\mathrm{C} 1\left[\left(\mathrm{X} \rightarrow \mathrm{M}_{1} \rightarrow \mathrm{Y}_{\mathrm{VI}} * \mathrm{X} \rightarrow \mathrm{M}_{1} \rightarrow \mathrm{M}_{2} \rightarrow \mathrm{Y}_{\mathrm{VI}}\right): .13\right.$, SE $=.02,95 \%$ CI $(.085, .195)]$ and $\mathrm{C} 2\left[\left(\mathrm{X} \rightarrow \mathrm{M}_{1} \rightarrow \mathrm{Y}_{\mathrm{VI}} * \mathrm{X} \rightarrow \mathrm{M}_{2} \rightarrow \mathrm{Y}_{\mathrm{VI}}\right): .16\right.$, $S E=.03,95 \% \mathrm{CI}(.097, .232)]$. 


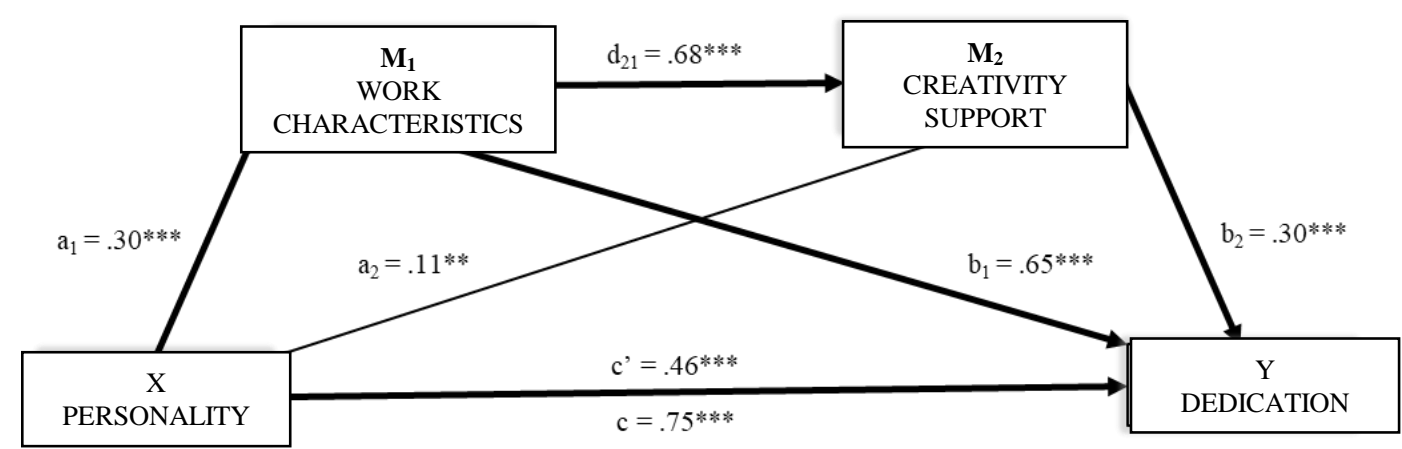

Figure 3. Multiple mediation model for Dedication $\left(\right.$ Note. $\left.{ }^{* *} p<.01,{ }^{* * *} p<.001\right)$.

Finally, in Figure 4, the Absorption factor is the dependent variable, with significant effects of Personality $(B=.21$, $p$ $<.001)$, Work characteristics $(B=.50, p<.001)$, and Creativity support $(B=.26, p<.001)$. The total effect of the model was also significant $(B=.45, p<.001)$. The analysis of indirect effects found significant values for Path 1 [ind : $_{1}$ $\mathrm{X} \rightarrow \mathrm{M}_{1} \rightarrow \mathrm{Y}_{\mathrm{AB}} ; B=.15, S E=.02,95 \%$ CI $\left.(.109, .207)\right]$, Path 2 [ind $2: \mathrm{X} \rightarrow \mathrm{M}_{1} \rightarrow \mathrm{M}_{2} \rightarrow \mathrm{Y}_{\mathrm{AB}} ; B=.05$, SE $=.01,95 \%$ CI (.035,
$.080)$ ] and Path 3 [ind $3: \mathrm{X} \rightarrow \mathrm{M}_{2} \rightarrow \mathrm{Y}_{\mathrm{AB}} ; B=.03, \mathrm{SE}=.01$, $95 \%$ CI $(.008, .058)]$. The data from the comparisons of mediators showed significant differences between the indirect effects compared in $\mathrm{C} 1\left[\left(\mathrm{X} \rightarrow \mathrm{M}_{1} \rightarrow \mathrm{Y}_{\mathrm{VI}} * \mathrm{X} \rightarrow \mathrm{M}_{1} \rightarrow \mathrm{M}_{2} \rightarrow \mathrm{Y}_{\mathrm{VI}}\right)\right.$ : $.09, S E=.02,95 \%$ CI $(.052, .151)]$ and $\mathrm{C} 2\left[\left(\mathrm{X} \rightarrow \mathrm{M}_{1} \rightarrow \mathrm{Y}_{\mathrm{VI}} *\right.\right.$ $\left.\left.\mathrm{X} \rightarrow \mathrm{M}_{2} \rightarrow \mathrm{Y}_{\mathrm{VI}}\right): .12, S E=.02,95 \% \mathrm{CI}(.069, .185)\right]$.

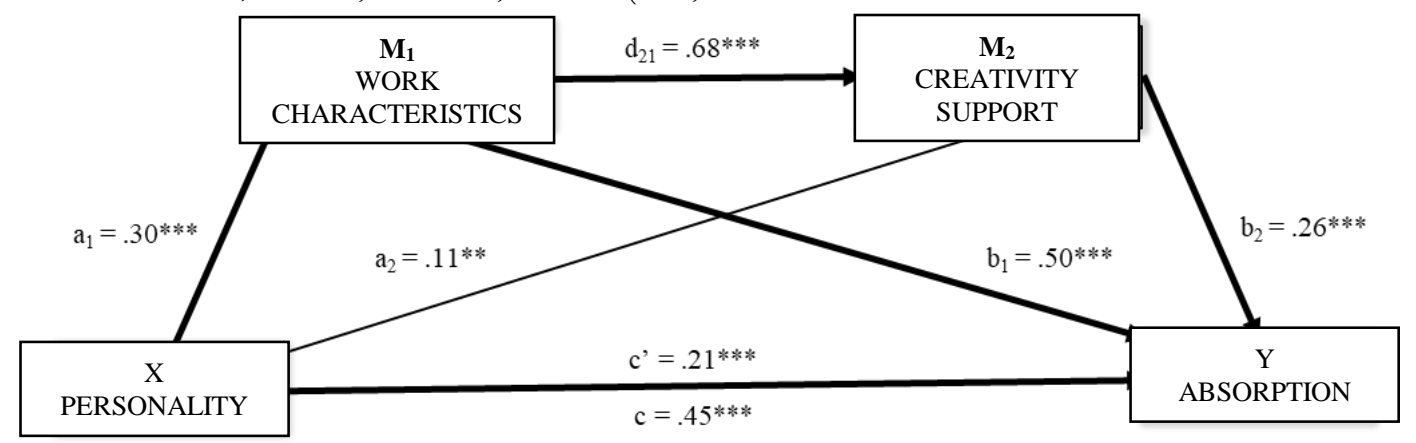

Figure 4. Multiple mediation model for Absorption (Note. $\left.{ }^{* *} p<.01,{ }^{* * *} p<.001\right)$

\section{Discussion}

With regard to the first objective of this study, the correlational analysis revealed that there were high positive correlations between Personality (Conscientiousness component) and Engagement (Dedication dimension), and between engagement and Perception of creativity. Dedication explained $30.9 \%$ of the Perception of creativity (Creativity support and Work characteristics). Cluster analysis identified two nursing personality profiles, meeting our second research objective. The first cluster was made up of nurses with lower scores on all the personality factors except Neuroticism. Thus, some authors suggest that the personality factors, except Neuroticism, are positively related to subjective vitality (Bhargavi et al., 2017; Pillai, 2018; Uysal et al., 2014). Personality was also found to influence Perception of creativity in the work context and in the components of Engagement in nurses. The cluster analysis showed that nurses in Cluster 2 (with high scores in all the personality dimensions and lower in Neuroticism), showed more engagement with their work, and that nurses in Cluster 1 (with lower scores on all the personality dimensions except Neuroticism) showed stronger blocks to being creative. These results coincide with the findings of other authors on the relationship between personality and creativity (Romo et al., 2017; Sanz de Acedo et al., 2014; Werner et al., 2014) and personality and job engagement (Mesurado et al., 2018; Panacio \& Vandenberghe, 2012; Taris et al., 2017; Tisu et al., 2020). The study by Krumm et al. (2018) related Creativity support to all the personality factors except Neuroticism. On this subject, other authors emphasize the role of creative personality in the creativity of nursing students (Hsing-Yuan, 2020) and how creativity favors self-critical thought (Furnham et al., 2013; Taherinejad et al., 2017). We agree with Nurhasanah et al. (2020) that the characteristics of personality exert a relevant role in professional performance. Thus, the most creative nurses are more likely to fulfill their duties (Amorós et al., 2019) and participate in their work by contributing new ideas (Liu et al., 2020; Martínez-Loredo et al., 2018). Finally, with respect to the third objective, the mediation analysis confirmed a model by 
which perception of creativity in the work context had a mediating role in the relationship between personality and engagement.

The practical implications of this study are related to the need to consider the role of engagement in perception of creativity in the work of healthcare personnel. This study shows how certain personality traits, such as neuroticism, should be kept within lower limits to increase engagement and improve creativity. Furthermore, in all of this fabric, other variables, such as work team climate, social support, job satisfaction and emotional intelligence, should also be considered to improve creativity. New studies could relate these variables to personality characteristics, the perception of creativity and engagement. Thus, all those interventions for improving work engagement would contribute to some extent to the development of perception of creative organizational settings. The personality profiles found also revealed that high scores on all the personality dimensions except neuroticism increase job commitment and just the opposite blocks creativity.

Among the limitations of this study is the selection of questionnaires. Specifically, the BFI-10 for personality, which although its properties are adequate, is a brief format, and should be completed with other more complex tests (projective tests, interviews, direct observation). The sample evaluated is also specific and limited to a single health profession, nursing. It is possible that the results cannot be generalized to other related professionals in this area. Finally, as it is a cross-sectional study, these findings should be corroborated in longitudinal designs enabling cause-effect relationships to be established between the variables studied.

\section{References}

Abbas, A., Barhani, F., Forogh, G., y Najmi, S. (2013). La relación entre la angustia moral de las enfermeras que trabajan: Un estudio descriptivo de la comunicación [The relationship between the moral anguish of working nurses: A descriptive study of communication] Revista de Ética Médica, 7(24), 33-53.

Amorós, E., Esquerda, M., Agustí, A. M., Kiskerri, A., Prat, J., Viñas, J., y Pifarré, J. (2019). Have millennials arrived at Medical School? Personality profile of medical students 1999-2014. Educación Médica, In Press. https://doi.org/10.1016/j.edumed.2018.12.007

Bakioğlu, F., y Kiraz, Z. (2019). Burnout and Wellbeing of Teacher Candidates: The Mediator Role of Cynicism. Annals of Psychology, 35(3), 521528. http://dx.doi.org/10.6018/analesps.35.3.3544141

Bakker, A. B, y Demerouti, E. (2013). Job demands resources model. Jour nal of Work and Organizational Psychology, 29, 107-115. http://dx.doi.org/10.5093/tr2013a16

Belsley, D. A. (1991). A guide to using the collinearity diagnostics. Computer Science in Economics and Management, 4(1), 33-50.

Bhargavi, N., Samuel, A., y Paul, P. (2017). Intragenerational Differences in Personality Traits of Millennial Leaders in Indian IT Sector. International Business Management, $11(6), \quad 1254-1262$. http://dx.doi.org/10.36478/ibm.2017.1254.1262

Boada-Grau, J., Sánchez-García, J. C., PrizmicKizmica-Kuzmica, A. J., y Vigil-Colet, A. (2014). Adaptación de la escala Creative Environment

\section{Conclusions}

The most relevant contributions of this study are related to the role of personality traits in the perception of job creativity on engagement of nursing personnel. The mediation model confirmed that the perception of creativity in the work context exerted a mediating role in the relationship between personality and engagement. In particular, it presents a personality profile with high scores on all the dimensions of personality except neuroticism, making adequate work characteristics possible, favoring creativity support, which in turn, has positive repercussions on engagement. This study has important implications for professional practice, emphasizing the strong relationship between engagement and perception of creativity. This leads to the improved perception of creativity and engagement of nursing personnel with their work, improving emotional stability and reinforcing enthusiasm and inspiration to be more creative and competent within the institutional organization they are part of. These findings probably contribute to the selection of profiles in agreement with companies that promote creativity and thereby engagement.

Acknowledgments.- This study has the collaboration of the Excma. Diputación Provincial de Almería. Part of this work has been carried out thanks to the Aid for Predoctoral Contracts for the training of Doctors (PRE2018-085434) granted to José Gabriel Soriano Sánchez within the project with Reference: EDU201788139-R financed by the State Program for Research, Development and Innovation Oriented to the Challenges of Society, within the framework of the State Plan for Scientific and Technical Research and Innovation, and co-financing with Structural Funds of the European Union; as well as funding for the Training of University Teaching Staff in Deficit Areas, Gerty Cori Grants, for the help for the hiring of research personnel in predoctoral training, granted to María del Mar Simón Márquez.

Perceptions al español [Adaptation of the Creative Environment Perceptions scale to Spanish]. Universitas Psychologica, 13(4), 1357-1366. http://dx.doi.org/10.11144/Javeriana.UPSY13-4.aece

Çelik, G. T., y Oral, E. L. (2016). Big Five and Organizational Commitment - The Case of Turkish Construction Professionals. Human Resource Management Research, 6(1), 6-14. http://dx.doi.org/10.5923/j.hrmr.20160601.02

Chang, H. T., Chou, Y. J., Liou, J. W., y Tu, Y. T. (2016). The effects of perfectionism on innovative behavior and job burnout: Team workplace friendship as a moderator. Personality and Individual Differences, 96 , 260-265. http://dx.doi.org/10.1016/j.paid.2016.02.088

Cheng, L., Cui, Y., Chen, Q., Ye, Y., Liu, Y., Zhang, F., Zeng, W., y Hu, X. (2020). Paediatric nurses' general self-efficacy, perceived organizational support and perceived professional benefits from Class A tertiary hospitals in Jilin province of China: the mediating effect of nursing practice environment. BMC Health Services Research, 20(1), 12 http://dx.doi.org/10.1186/s12913-019-4878-3

Cohen, J. (1988). Statistical Power Analysis for the Behavioral Sciences (2nd ed.). Hillsdale, NJ: Lawrence Erlbaum Associates, Publishers.

Deniz, M. E., y Satici, S. A. (2017). The Relationships between Big Five Personality Traits and Subjective Vitality. Anales de Psicología, 33, 218224. http://dx.doi.org/10.6018/analesps.33.2.261911 
Domínguez-Lara, S. (2018). Fiabilidad y alfa ordinal [Reliability and ordinal alpha]. Actas Urológicas Españolas, 42(2), 140-141. http://dx.doi.org/10.1016/j.acuro.2017.07.002

Elosua, P., y Zumbo, B. D. (2008). Coeficientes de fiabilidad para escalas de respuesta categórica ordenada [Reliability coefficients for ordered categorical response scales]. Psicothema, 20(4), 896-901. http://dx.doi.org/10.1007/BF02310555

Freiberg, A., de la Iglesia, G., Stover, J., y Fernández, M. (2014). Escala de personalidad paradójica: su desarrollo y análisis de validez de constructo [Paradoxical personality scale: its development and construct validity analysis]. International Journal of Psychological Research, 7(1), 49-72.

Furnham, A., Hughes, D. J., y Marshall, E. (2013). Habilidades de pensamiento y creatividad [Thinking and creativity skills]. Thinking Skills and Creativity, 10, 91-98. http://dx.doi.org/10.1016/j.tsc.2013.05.003

García, J. J., Labajos, M. T., y Fernández, F. (2015). Los estudiantes de Grado en Enfermería y su compromiso con los estudios [Nursing Degree students and their commitment to studies]. Enfermeria Global, 38, 169-177. https://doi.org/10.6018/eglobal.14.2.198261

Hayes, A.F. (2009). Beyond Baron and Kenny: Statistical mediation analysis in the new millennium. Communication monographs, 76(4), 408-420.

Hayes, A. F. (2013). Introduction to Mediation, Moderation, and Conditional Process Analysis: A Regression-Based Approach. New York, EE.UU: The Guilford Press.

Hsing-Yuan, L. (2020). Factors affecting nursing students' creativity in Taiwan: Exploring the moderating role of creative personality. Nurse Education Today, 88, 104367. https://doi.org/10.1016/j.nedt.2020.104367

John, O. P., Donahue, E. M., y Kentle, R. L. (1991). The Big Five InventoryVersions $4 a$ and 54. Berkeley, CA: University of California, Berkeley, Institute of Personality and Social Research.

John, O. P., Naumann, L. P., \& Soto, C. J. (2008). Paradigm shift to the integrative Big Five trait taxonomy: History, measurement, and conceptual issues. In O. P. John, R. W. Robins, \& L. A. Pervin (Eds.), Handbook of personality: Theory and research (pp. 114-158). New York, NY: Guilford Press.

Krumm, G., Lemos, V., y Richaud, M. C. (2018). Personality and Creativity: A Study in Spanish-Speaking Children. International Journal of Psychological Research, 11(1), 33-41. http://dx.doi.org/10.21500/20112084.2867

Langelaan, S., Bakker, A. B., Van Doornen, J. P., y Schaufeli, B. (2006). Burnout y trabajo de compromiso: ¿Las diferencias individuales hacen diferencia? [Burnout and engagement work: Do individual differences make a difference?] Personalidad y Diferencias Individuales, 8(3), 40-49.

Lcho, V., Biswas, B., y Choudhuri, M. (2019). Nurses competence level and its relationship with their personality traits and emotional intelligence in selected hospitals, Kolkata. Global Journal for Research Analysis, 8(6), 6165. http://dx.doi.org/10.15373/22778160

Liu, H. Y., Chang, C. C., Wang, I. T., y Chao, S. Y. (2020). The association between creativity, creative components of personality, and innovation among Taiwanese nursing students. Thinking Skills and Creativity, 35, 1 9. http://dx.doi.org/10.1016/j.tsc.2020.100629

Liu, J. N. M., y Johnston, J. M. (2019). Working while sick: Validation of the multidimensional presenteeism exposures and productivity survey for nurses (MPEPS-N). BMC Health Services Research, 19(1), 542. https://doi.org/10.1186/s12913-019-4373-x

Lorenzo-Seva, U., y Ferrando, P. J. (2006). FACTOR: A computer program to fit the exploratory factor analysis model. Behavior Research Methods, 38(1), 88-91. https://doi.org/10.3758/BF03192753

Manso, C., Cuevas, A., y González, S. (2019). Competencias informacionales en los estudios de grado en enfermería: el caso español [Informational competences in nursing degree studies: the Spanish case]. Revista Española de Documentación Cientifica, 42(1), e229. http://dx.doi.org/10.3989/redc.2019.1.1578

Martínez-Loredo, V., Cuesta, M., Lozano, L. M., Pedrosa, I., y Muñiz, J. (2018). Multifactor implicit measures to assess enterprising personality dimensions. $\quad$ Psicothema, 30(4), 357-363. doi: $10.7334 /$ psicothema2018.204

Mayfield, M., y Mayfield, J. (2010). Developing a scale to measure the creative environment perceptions: A questionnaire for investigating gardenvariety creativity. Creativity Research Journal, 22(2), 162-169. http:/ /dx.doi.org/10.1080/10400419.2010.481511
Mesurado, B., Tortul, M. C., y Schonfeld, F. (2018). Cinco grandes rasgos de personalidad: su relación con el flujo y el compromiso académico [Five Great Personality Traits: Their Relationship to Flow and Academic Engagement]. Revista Contextos de Educación, 25, 150-158.

Molero, M. M., Pérez-Fuentes, M. C., Gázquez, J. J., y Barragán, A. B. (2018). Burnout in Health Professionals According to Their SelfEsteem, Social Support and Empathy Profile. Frontiers in Psychology, 9, 1-6. http://dx.doi.org/10.3389/fpsyg.2018.00424

Montgomery, A., Spânu, F., Băban, A., y Panagopoulou, E. (2015). Job demands, burnout, and engagement among nurses: A multi-level analysis of ORCAB data investigating the moderating effect of teamwork. $\begin{array}{lll}\text { Burnout Research, 2(2-3), 71-79. } & \end{array}$ https://doi.org/10.1016/j.burn.2015.06.001

Mussons, M., y Tarrats, E. (2018). Modelo de Credibilidad Emprendedora en los estudiantes de enfermería y fisioterapia [Entrepreneurial Credibility Model in nursing and physiotherapy students]. Revista Electrónica Trimestral de Enfermería, 17(49), 294-308. http://dx.doi.org/10.6018/eglobal.17.1.280281

Njoku, E. C., Ebeh, R. E., y Okwuchukwu, S. (2017). Personality traits as predictors of organizational commitment among public and private sector employees in Enugu, Nigeria. British Journal of Psychology Research, 5(2), 9-23. http://dx.doi.org/10.5923/j.hrmr.20160601.02

Nurhasanah, Riyanto, A., y Novitasari, D. (2020). The Effect of Personality, Organizational Citizenship Behaviour, Stress toward Hospital Nurses Performance in Bengkulu City. Test Engineering and Management, 82, 3300-3306.

Othman, N., y Nasurdin, A. M. (2019). Job characteristics and staying engaged in work of nurses: Empirical evidence from Malaysia. International Journal of Nursing Sciences, 6(4), 432-438. https://doi.org/10.1016/j.ijnss.2019.09.010

Panacio, A., y Vandenberghe, C. (2012). Modelo de cinco factores de personalidad y compromiso organizacional: el papel mediador de los estados afectivos positivos y negativos [Five-factor model of personality and organizational commitment: the mediating role of positive and negative affective states]. Journal of Vocational Behavior, 80(3), 647-658. http://dx.doi.org/10.1016/ j.jvb.2012.03.002

Pérez-Fuentes, M.C., Molero, M.M., Martos, Á., y Gázquez, J. J. (2019a). Burnout and engagement: Personality profiles in nursing professionals. Journal of Clinical Medicine, 8(3), 286. https://doi.org/10.3390/jcm8030286

Pérez-Fuentes, M. C., Molero, M. M., Gázquez, J. J., y Oropesa, N. F. (2018). The Role of Emotional Intelligence in Engagement in Nurses. International Journal of Environmental Research and Public Health, 15(9), 1915. https://doi.org/10.3390/ijerph15091915

Pérez-Fuentes, M. C., Molero, M. M., Barragán, A. B., Simón, M. M., Martos, Á., y Gázquez, J. J. (2019b). The mediating role of perceived stress in the relationship of self-efficacy and work engagement in nurses. Journal of Clinical Medicine, $8(1), \quad 1-10$. https://doi.org/10.3390/jcm8010010

Pillai, P. (2018). Happiness and Personality Traits of Care Professionals: A Comparative Analysis of Nurses in Kerala. International Conference on Management and Information Systems, 21-22, 40-46. https://doi.org/10.9790/1959-05164447

Rammstedt, B., Kemper, C. J., Klein, M. C., Beierlein, C., y Kovaleva, A. (2014). Big Five Inventory (BFI-10). Zusammenstellung sozialwissenschaftlicher Items und Skalen. http://dx.doi.org/10.6102/zis76

Rammstedt, B., y John, O. P. (2007). Measuring personality in one minute or less: A 10-item short version of the Big Five Inventory in English and German. Journal of Research in Personality, 41, 203-212. https://doi.org/10.1016/j.jrp.2006.02.001

Robins, T. G., Roberts, R. M., y Sarris, A. (2018). Understanding How Personality Impacts Exhaustion and Engagement: The Role of Job Demands, and Job and Personal Resources as Mediators. Australian Psychologist, 53(3), 253-262. https://doi.org/10.1111/ap.12310

Romo, M., Sánchez-Ruiz, M. J., y Alfonso-Benlliure, V. (2017). Creatividad y personalidad a través de dominios: una revisión crítica [Creativity and personality across domains: a critical review]. Anuario de Psicología, 47, 64-65. http://dx.doi.org/10.1016/j.anpsic.2017.04.003 
Sanz de Acedo, M. L., Sanz de Acedo, M. T., y Closas, A. H. (2014). Un modelo explicativo sobre las relaciones entre los rasgos psicológicos y la creatividad [An explanatory model on the relationships between psychological traits and creativity.]. Anales de Psicologia, 30(1), 355-363. http://dx.doi.org/10.6018/analesps.30.1.153781

Schaufeli, W. B., y Bakker, A. B. (2003). UWES-Utrecht Work Engagement Scale: Test manual. Utrech, Netherlands: Utrech University.

Sovia, Suharti, Yellyanda, Abbasiah, y Nomiko, D. (2018). Factors affecting the performance of public health nurses in family nursing care. Enfermería Clínica, 29(1), 74-77. https://doi.org/10.1016/j.enfcli.2018.11.024

Taherinejad, Z., Ahmad, S., Amani, R., y Sadat, M. (2017). Relationship emotional intelligence and personality traits with organizational commitment among Iranian nurses. Journal of Research y Health, 7(1), 614 623. http://dx.doi.org/10.18869/ acadpub.jrh.7.1.614

Taris, T. W., Ybema, J. F., y van Beek, I. (2017). Burnout and engagement: Identical twins or just close relatives? Burnout Research, 5, 3-11. http://dx.doi.org/10.1016/j.burn.2017.05.002

Tehrani, H., Rakhshani, T., Zadeh, D. S., Hosseini, S. M., y Bagheriyan, S. (2013). Analyzing the Relationship Between Job Stress to Mental Health, Personality Type And Stressful Life Events of the Nurses Occupied in Tehran 115 Emergency. Iranian Red Crescent Medical Journal, 15(3), 272-273. http://dx.doi.org/10.5812/ircmj.1917

Tisu, L., Lupsa, D., Vîrgă, D., y Rusu, A. (2020). Personality characteristics, job performance and mental health the mediating role of work en- gagement. Personality and Individual Differences, 153(15), 109644. https://doi.org/10.1016/j.paid.2019.109644

Uysal, R., Satici, S. A., Satici, B., y Akin, A. (2014). Subjective vitality as mediator and moderator of the relationship between life satisfaction and subjective happiness. Educational Sciences: Theory and Practice, 14(2), 489497. http://dx.doi.org/10.12738/estp.2014.2.1828

Vizoso-Gómez, C., y Arias-Gundín, O. (2018). Resiliencia, optimismo y burnout académico en estudiantes universitarios [Resilience, optimism and academic burnout in university students]. European Journal of Educa$\begin{array}{lll}\text { tion } & \text { and } & \text { Psychology, }\end{array}$ http://dx.doi.org/10.30552/ejep.v11i1.185

Werner, C. H., Tang, M., Kruse, J., Kaufman, J. C., y Sporrle, M. (2014) The chinese version of the revised creativity domain questionnaire (CDQ-R): First evidence for its factorial validity and systematic association with the big five. The Journal of Creative Behavior, 4, 254-275. http://dx.doi.org/10.1002/jocb.51

Xu, X., Jiang, L., y Wang, H. J. (2019). How to build your team for innovation? A cross-level mediation model of team personality, team climate for innovation, creativity, and job crafting. Journal of Occupational and $\mathrm{Or}$ ganizational Psychology (2019), 92, 848-872. http://dx.doi.org/10.1111/joop.12277

Yan, X., Su, J., Wen, Z., y Luo, Z. (2019). The Role of Work Engagement on the Relationship Between Personality and Job Satisfaction in Chinese Nurses. Current Psychology, 38(3), 873-878. http://dx.doi.org/10.1007/s12144-017-9667-8. 